International Journal of Environment, Agriculture and Biotechnology
Vol-6, Issue-6; Nov-Dec, 2021
J Journal Home Page Available: https://ijeab.com/
Journal DOI: $10.22161 /$ ijeab

\title{
Mitigating an Airport's Carbon Footprint Through the Use of "Green" Technologies: The Case of Brisbane and Melbourne Airports, Australia
}

\author{
Glenn Baxter
}

School of Tourism and Hospitality Management, Suan Dusit University, Thailand.

Received: 10 Sep 2021; Received in revised form: 27 Oct 2021; Accepted: 05 Nov 2021; Available online: 12 Nov 2021

C2021 The Author(s). Published by Infogain Publication. This is an open access article under the CC BY license

(https://creativecommons.org/licenses/by/4.0/).

\begin{abstract}
Like many other airports located around the world, Australia's major airports have installed and are operating new green energy systems, such as, photovoltaic $(P V)$ solar and trigeneration systems. Using an instrumental case study research approach, this study has examined how Brisbane and Melbourne Airports have mitigated their carbon footprint by using green, renewable energy systems. The extensive use of these green, renewable energy has enabled both Brisbane and Melbourne Airports to reduce their annual carbon dioxide $\left(\mathrm{CO}_{2}\right)$ emissions, and thus, these measures have helped to mitigate the environmental impact of these airports' operations. The study revealed that the photovoltaic $(P V)$ solar system at Brisbane Airport, will enable the airport to reduce its annual carbon dioxide $\left(\mathrm{CO}_{2}\right)$ emissions by an estimated 8,000 tonnes per year. The trigeneration system installed and operated by Melbourne Airport will deliver an estimated reduction of 920,000 tonnes carbon dioxide $\left(\mathrm{CO}_{2}\right)$ emissions over a 15 period. Melbourne Airport's photovoltaic (PV) solar is also delivering a reduction in the airport's annual carbon dioxide $\left(\mathrm{CO}_{2}\right)$ emission.
\end{abstract}

Keywords - Airports, Brisbane Airport, Melbourne Airport; Photovoltaic (PV) systems, Solar power, Trigeneration

\section{INTRODUCTION}

In the global aviation industry, passenger and air cargo services are provided within a value chain with the key stakeholders comprising aircraft manufacturers, leasing firms, airlines, airports, air traffic control service providers, aircraft maintenance organizations, flight catering providers, aircraft refuellers, ground handling agents, global distribution systems (GDS), travel agents, tour operators, and air freight forwarders (Jarach, 2017; Tretheway \& Markhvida, 2013). Airports play a fundamental role in the air transport value by providing the critical infrastructure, such as, passenger terminals and runways that are necessary to facilitate the movement of passengers and air cargo. Accordingly, airports act as the critical interface point between the surface-based and air transport modes (Baxter et al., 2018a). Despite the significant social and economic benefits of air transport services, such services have an adverse impact on the environment. Noise, air and water pollution, and natural resources consumption present at an airport all have an adverse impact on the environment (Budd, 2017; Daley, 2016; Janić, 2011). In addressing their environmental impact concerns, airports are increasingly trying to become "green" or more environmentally friendly (Comendador et al., 2019; Janić, 2011). A "green airport" is an airport which has a minimal impact on the environment and is one that endeavors to become a carbon neutral facility in terms of carbon emissions, with the goal of producing zero greenhouse gas emissions (González-Ruiz et al., 2017).

In providing the necessary critical infrastructure, such as, runways, taxiways and airport facilities, airports consume large amounts of energy and, as such, are regarded as being very energy intensive (Akyuz et al., 2019; Baxter et al., 2018b; Ortego Alba \& Manana, 2017). Considering this, airports around the world are increasingly embracing green energy technologies, such as photovoltaic solar (PV) 
systems, as a way of mitigating their carbon footprint. Adelaide Airport, Cochin Airport, Osaka's Kansai Airport, and Raja Bhoj International Airport, for example, have all introduced photovoltaic solar (PV) systems.

The objective of this study is to examine the solar photovoltaic (PV) systems installed at Brisbane and Melbourne Airports, Australia and to identify the environmental benefits that these two airports have obtained from the use of these systems. A secondary objective was to examine the trigeneration system installed at Melbourne Airport and to identify how this system has enabled the airport to mitigate its carbon footprint. The Brisbane and Melbourne Airports photovoltaic (PV) systems formed the focus for this case study as these are the largest solar photovoltaic (PV) systems installed at any Australian airport. A further factor in selecting Brisbane and Melbourne Airports as the case airports was the readily available case documentation which allowed for the in-depth analysis of these airports adoption of green energy systems and technologies.

The remainder of the paper is organized as follows: the literature review presented in Section 2 sets the context for the in-depth case study. The research method used in the study is described in Section 3. The Brisbane and Melbourne Airports case study is presented in Section 4. The key findings of the study are presented in Section 5.

\section{BACKGROUND}

\subsection{Airport Energy Sources}

Airports are comprised of the landside and airside precincts (Janić, 2011, 2017). The airside precinct includes the aircraft movement area, and the adjacent terrain and buildings/infrastructure. The landside precinct includes those parts of an airport together with the adjacent terrain and buildings that are not located in the airside precinct (Rossi Dal Pozzo, 2015). The actors operating within the airport's airside and landside precincts require a reliable and highly efficient supply of energy. Historically, the two primary energy sources have been electricity and fuel, for example, diesel, natural gas, and propane (Ortega Alba \& Manana, 2016). Electrical energy is normally supplied directly to the airport through dedicated sub-stations (Janić, 2011). Typically, airports purchase electricity from the commercial grid and this electricity is supplied by a power company (Ortega Alba \& Manana, 2016). As previously noted, in recent times airports have increasingly adopted the use of renewable energy sources. These include solar photovoltaic, concentrating solar power, wind power, oil and natural gas extraction, steamgenerated power production and electricity transmission (Barrett et al., 2014). The use of renewable energy resources has provided airports with several favorable environmental related advantages. Green energy produces no greenhouse gas emissions from the combustion of fossil fuels. As a result, this reduces some forms of harmful air pollution (International Renewable Energy Agency, 2021; United States Environmental Protection Agency, 2021). Furthermore, renewable energy systems provide the airport with an alternative clean source of power (Kramer, 2010). Another important advantage is that solar power photovoltaic (PV) systems lower the airport's ground emissions (Sukumaran \& Sudhakar, 2017). The airport's carbon footprint (carbon dioxide $\mathrm{CO}_{2}$ emissions) can also be reduced by substituting solar PV based power generation for traditional, more heavily polluting, fossilfuel based energy sources (Sukumaran \& Sudhakar, 2017; Wybo, 2013). In addition, the use of green or renewable energy sources provides a firm or user with an important opportunity to optimize energy efficiency (Arman et al., 2013). Another advantage is that renewable energy sources normally have very little waste (Yerel Kandemir \& Yayli, 2016).

According to Sukumaran and Sudhakar (2017), "the amount of power that a solar PV system can produce at an airport is dependent upon the available area". The amount of power is also dependent upon the type of photovoltaic (PV) solar system used at the airport, the PV system's orientation, and the available solar resource (Kandt \& Romero, 2014). Many airports often have large tracts of open space that could be potentially used for the installation and operation of a PV system (Baek et al., 2016; Curran, 2016). Accordingly, many airports who meet the spare land use requirement are installing or plan to install large surfaces of PV panels (Figure 1). These PV systems are often capable of producing 20MWh or even higher amounts of sustainable energy (Wybo, 2013).

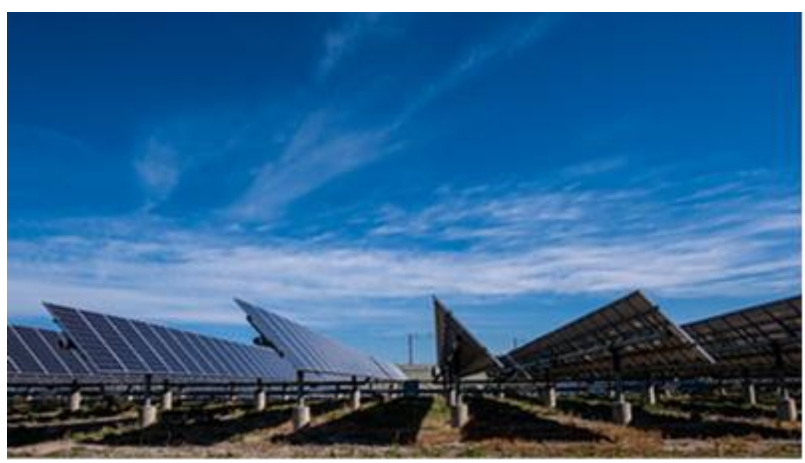

Fig. 1: Solar photovoltaic system installed at Denver International Airport. Photograph provided courtesy of Denver International Airport.

\subsection{Energy Usage at Airports}


The primary areas of energy consumption at an airport are heating, cooling, lighting, and the energy required for operating the airport's facilities and systems (Janić, 2011; Radomska et al., 2018). At many airports, crude oil is often used for producing the fuel used to power the ground service equipment (GSE) and vehicles that are used in an airport's airside and landside areas, especially in the aircraft ground handling process (Janić, 2011). Fuel is also used for airport's heating boiler systems and emergency generators (Ortega Alba \& Manana, 2016). The airport terminal's heating, ventilation, and air conditioning (HVAC) systems use the largest amount of energy (Akyüz et al., 2017).

\subsection{A Brief Overview of Photovoltaic (PV) Solar Systems and the Key Issues for Airports}

The solar photovoltaic (PV) systems being installed at airports are normally customized so that they optimize the use of the selected site (Baxter et al., 2019). Importantly, there are different environmental factors that will be applicable for each site. Consequently, these factors will influence the type of photovoltaic (PV) system that is required, and they will also impact its level of performance. Photovoltaic (PV) systems are comprised of the solar resource, photovoltaic cells, panel or module, array, battery, inverter, charge controller, electrical load this includes the appliances and other devices that use the energy generated by the PV system, wiring and the surge protector - this is a device that safeguards against electrical shock from short circuits and damaging power fluctuations. The photovoltaic (PV) system wiring includes the wires that are known as conductors that connect the system components to complete circuits (Balfour et al., 2013, pp. 4-5). Quite often photovoltaic solar systems are collective in nature, that is, they are centralized systems that provide electricity to a group of users. These users include commercial customers (Bhattacharyya, 2015).

As previously noted, there is a growing use of solar power at airports located right around the world (Sreenath et al., 2020, 2021a, 2021b). However, there are several key issues that airport's need to be cognizant of when considering the installation and use of a photovoltaic (PV) solar system (Baxter et al., 2019). Solar photovoltaic (PV) systems are required to be installed at a sufficient distance from the airport's runway(s) and these systems should adhere to all relevant safety and fire measures applicable at the airport (Kandt \& Romero, 2014). If inappropriately located at the airport, then there is a risk that the solar photovoltaic (PV) systems at airports can impact pilots, air-traffic controllers, aircraft, and air navigation systems due to the glare reflection (Mostafa et al., 2016). The solar system could cause either glint or glare, or possibly a combination both. This could potentially result in a brief loss vision, which would be an important safety concern for aircraft pilots (Anurag et al., 2017). Consequently, glare due to the reflection of sunlight from the metal parts of a solar PV panel could potentially provide a risk that may result in an adverse impact on aviation safety (Mostafa et al., 2016). There are several measures that an airport can use to mitigate the glare from their solar system. The first measure involves the application of antireflective coatings (Solanki \& Singh, 2017). The second measure involves the surface texturing of the systems panels (Ahmed et al., 2017). Neither of these measures should have a noticeable impact on the solar PV system performance but will greatly assist in minimizing reflection from the PV system (Kandt \& Romero, 2014).

\section{RESEARCH METHODOLOGY}

\subsection{Research Method}

This study used a qualitative instrumental case study research approach (Owens et al., 2021; Sorenson, 2021; West et al., 2021). An instrumental case study is the study of a case. An instrumental case study can study a firm(s). This research approach provides insights into a specific issue, enables researchers to redraw generalizations, or builds theory (Stake, 1995, 2005), whilst also facilitating the understanding of a specific phenomenon. An instrumental case study is designed around established theory (Grandy, 2010). The present study was designed around the established theory of green energy (Aswathanarayana, 2010; Bhowmik et al., 2017; Kalyani et al., 2015), and the use of solar power by airports (Baxter et al., 2019; Sreenath et al., 2020, 2021a, 2021b; Sukumaran \& Sudhakar, 2017).

\subsection{Data Collection}

Data for the study was obtained from a variety of documents, airport industry-related journals, annual reports, press releases, company materials available on the internet and records as sources of case evidence. Documents included Brisbane and Melbourne Airports environmental policies, Brisbane Airport's masterplan, industry publications, and the airport's websites. Thus, this study used secondary data. The study followed data collection guidance of Yin (2018), that is, multiple sources of case evidence were used, a database on the subject was created, and there was of a chain of case evidence.

\subsection{Data Analysis}

Document analysis was used to analyze the documents gathered for the study. Document analysis focuses on the information and data from formal documents and company records that are gathered by the researcher(s) when conducting their case study (Andrew et al., 2011; Oates, 
2006; Yin, 2018). The study paid particular attention to four criteria that need to be carefully considered when assessing the quality of historical documents: authenticity, credibility, representativeness and meaning (Scott, 2014; Scott \& Marshall, 2009).

The document analysis process was undertaken in six discrete stages. Firstly, the types and required documentation and their availability were ascertained. In the second stage, the pertinent documents were collected and a system for managing them was developed. In the next stage, the documents were reviewed to assess their authenticity, credibility. It was also necessary to ascertain if any potential bias existed in the documents. The fourth stage involved the interrogation of the documents at which time the key themes, data and issues were identified. This was followed by a period of reflection and refinement at which time any difficulties with the documents were identified. Also, in this stage, a thorough review of the sources and the documents content was undertaken. The analysis of the data was finalized in the sixth stage of the document analysis process (O’Leary, 2004).

All the documents collected for the study were stored in a case study database (Yin, 2018). All the study's documents were in English. Each document was carefully read, and key themes were recorded in the case study (Baxter, 2021).

\section{RESULTS}

\subsection{Brisbane Airport Photovoltaic (PV) Solar System}

\subsubsection{A Brief Overview of Brisbane Airport}

Brisbane Airport is bounded by the Brisbane River to the east, the Kedron Brook Floodway to the west, Moreton Bay to the north and the Gateway Motorway to the south of the airport precinct. The airport is located less than 20 kilometres from the Brisbane central business district (CBD) (Brisbane Airport, 2020). Brisbane Airport, IATA airport code BNE, is Australia's largest airport by land area (Brisbane Airport, 2021). The Brisbane Airport site is 2,700 hectares in size (Brisbane Airport, 2020). The airport has two separate terminals for domestic and international flights. The airport terminals are 4 kilometers apart. The international terminal has twelve gates with air bridges, two of which can handle the Airbus A380 aircraft. The domestic terminal has three satellites housing additional boarding gates and lounge facilities. There are twentyeight gates with air bridges (Brisbane Airport, 2021). Brisbane Airport has two runways.

In July 1997, the Commonwealth Government entered into a 50-year lease agreement with the new owners and operators of Brisbane Airport as part of the government's airport privatization policy (Graham, 2018; Paul \& De
Groot, 2010; Solomon, 2009). Brisbane Airport Corporation Pty Limited, the operator of Brisbane Airport, is a private, unlisted Queensland-based business. Brisbane Airport Corporation acquired Brisbane Airport from the Australian Federal Government in 1997 under a 50-year lease agreement with an option to renew for a further 49 years (Brisbane Airport, 2020, p. 29).

Brisbane Airport is a key hub for Qantas Airways, Jetstar Airways and Virgin Australia. The airport is also linked to major international air travel markets and is well served by international airlines, such as, Air New Zealand, Qantas, and Singapore Airlines amongst others.

\subsubsection{Brisbane Airport Environment and Sustainability Policy}

The Brisbane Airport Corporation (BAC) is firmly committed to reducing the impact on the environment and has implemented programs to manage and minimize the long-term impacts of climate change and adverse environmental impacts from aviation and property-related development activities at the airport (Brisbane Airport, 2020).

The airport operator has the overall environmental responsibility for all the activities and operations undertaken at the airport. These include all airport operations and security, asset management, tenancy management as well as development projects. All other airport users are also responsible for the environmental management of their activities (Brisbane Airport, 2020).

In accordance with their Environment and Sustainability Policy, Brisbane Airport Corporation is committed to:

- Operating, managing, and developing Brisbane Airport in an environmentally responsible manner.

- Ensuring compliance with the applicable environmental laws, policies and other legal requirements which pertain to its operation. The airport aims to striving to meet and/or exceed these requirements wherever possible.

- Fostering an environmentally responsible culture amongst the company's employees.

- Minimizing adverse impacts on the environment that are caused by the company's operations.

- Continually striving to reduce natural resource consumption, waste generation, and prevent pollution.

- Working closely with government departments, agencies, and airlines to manage impacts of aircraft noise and the impacts of aviation on the community. 
- Constantly striving to achieve continual improvement in environmental and sustainability performance through the implementation of an Environmental Management System (EMS) consistent with the international standard ISO14001:2015 and sustainability benchmarking evaluations (Brisbane Airport, 2020, p. 387).

To achieve this commitment, Brisbane Airport Corporation (BAC) will:

Take action to address potentially adverse environmental impacts.

- Communicate the Brisbane Airport Environment Strategy, policies and performance to employees, regulators, tenants, and the wider community.

- Establish, implement, and maintain an Environmental Management System (EMS) which includes the setting and reviewing of environmental objectives and targets.

- Periodically review the effectiveness of the Environmental Management System, and identify opportunities for environmental, social, economic, and operational sustainability performance improvements.

- Maximize energy, water, and waste efficiencies.

- Manage noise impacts, pollutant emissions and the impacts of climate change on the airport.

- Identify and seek to conserve objects and matters at the airport that have natural, indigenous, or historic heritage value.

- Achieve best practice in sustainable property development.

- Provide appropriate environmental training to the company's employees and encourage its tenants and contractors to do likewise.

- Build strong and active relationships with the wider community through engagement and sponsorship programs; and

- Provide the company's staff and resources necessary to meet these policy objectives (Brisbane Airport, 2020, p. 387).

4.1.3 Brisbane Airport Environmental Management System (EMS)

The Brisbane Airport Corporation Environmental Management System (EMS) has been developed in line with the internationally recognized EMS ISO 14001:2015 standard (Brisbane Airport, 2020). ISO 14001 is a worldwide meta-standard for implementing Environmental Management Systems (EMS) (Dentch, 2016; Grover \&
Grover, 2017; Heras-Saizarbitoria et al., 2011). The ISO 14001 Environmental Management System (EMS) has become one of the most widely used systems for managing corporate environmental aspects (Oliveira et al., 2011).

Brisbane Airport's EMS ensures that there is a systematic approach to manage environmental issues across the airport. Procedures and guidelines have been developed that are in accordance with specific aspects of the standard. These include:

- $\quad$ Risk and opportunities assessment.

- Compliance obligations.

- Training.

- Internal and external communications.

- Environmental auditing and document control.

- Incident and emergency preparedness.

- Sustainable procurement (Brisbane Airport, 2020, p. 389).

4.1.4 An Overview of Brisbane Airport's Photovoltaic (PV) Solar System

In 2017, Brisbane Airport made the decision to install a large photovoltaic (PV) solar system at the airport. The new 6MW photovoltaic (PV) solar system was to be installed across six sites at the airfield (Australian Aviation, 2019a; Shakra Energy, 2019). The system consists of five roof-mounted solar arrays which can generate a total of $5 \mathrm{MW}$, and one ground-mounted solar array, generating about 1MW (Ecogeneration, 2017). The system collectively covers 36,000 square meters (Australian Aviation, 2019a; Maisch, 2019, Trina Solar, 2019).

In Stage one, which ran from early April 2018 to mid-May 2018, 700 solar roof panels, generating 0.2MWp, were installed at the Skygate facility. The Skygate facility is in the airport's "The Circuit" precinct. In Stage two, which also ran from early April 2018 to mid-May 2018, 700 solar roof panels generating $0.2 \mathrm{MWp}$ were installed at the Department of Home Affairs building, which is also located in the airport's "The Circuit" precinct. During Stage 3, which ran from mid-July 2018 to September 2018, 3,500 solar roof panels, generating $1.03 \mathrm{MWp}$, were installed on the roof of the airport's domestic passenger terminal P1 multi-level car park. In Stage 4, which ran from mid-July 2018 to mid-October 2018, 3,400 solar panels generating $1.51 \mathrm{MWp}$, were installed on the roof of the airport's domestic terminal P2 multi-level car park. During Stage 5, which covered the period mid-May2018 to mid-October 2018, 6,545 solar roof panels generating $1.8 \mathrm{MWp}$ were installed on the roof of the airport's international passenger terminal building. In the final 
stage, which ran from early June 2018 to December 2018, 4,000 solar ground panels generating $1.01 \mathrm{MWp}$ were installed in Brisbane Airport's Pandanus Avenue precinct (Brisbane Airport, 2018).

At the time of the installation of the photovoltaic (PV) solar system, the airport's international terminal roof installation was the largest single roof photovoltaic (PV) solar power installation in Australia. The photovoltaic (PV) solar power system installed on the roof of the airport's international passenger terminal consists of 7,133 solar panels that measured 11,675 square metres in area (Australian Aviation, 2017, 2019a; Brisbane Development, 2017; Halcol Energy, 2019).

The installation of the complete photovoltaic (PV) solar power system took one year to complete, and the solar panels became operational at the end of 2018 (Halcol Energy, 2019).

Brisbane Airport did not rely upon any grants or subsidies apart from "Large-scale Generation Certificates" (Ecogeneration, 2017). In Australia, large-scale renewable energy projects, such as solar farms, are entitled to create large-scale generation certificates (LGCs). One LGC is equivalent to $1 \mathrm{MWh}$ of renewable electricity generated above the power station baseline (Clean Energy Regulator, 2021b). In Australia, it is permissible for Registered LGCs to be sold or transferred to entities with liabilities under Australia's Renewable Energy Target or to other companies who are seeking to voluntarily surrender LGCs. Liable entities are businesses (principally electricity retailers) that are required to purchase and surrender LGCs to Australia's Clean Energy Regulator each year in fulfilment of their obligations under the Renewable Energy (Electricity) Act 2000 (Clean Energy Regulator, 2021a).

4.1.5 The Environmental Related Benefits of Brisbane Airport Photovoltaic (PV) Solar System

The photovoltaic (PV) solar system has provided Brisbane Airport with some important environmental related benefits. It has been estimated that around $18 \%$ of the airport's electricity will be supplied from the solar PV system and this will meet approximately $6 \%$ of Brisbane Airport Corporation's overall load (Australian Aviation, 2019a; Brisbane Airport, 2018; Lenaghan, 2017). In addition, the photovoltaic (PV) solar system has reduced carbon dioxide $\left(\mathrm{CO}_{2}\right)$ emissions at the airport by an estimated 8,000 tonnes per year (Brisbane Airport, 2018).

\subsection{Melbourne Airport Photovoltaic (PV) Solar and Trigeneration Energy Systems}

\subsubsection{A Brief Overview of Melbourne Airport}

Melbourne Airport was officially opened on 1 July 1970 (Melbourne Airport, 2017a). The airport is located approximately 25 kilometres north-west of the Melbourne city central business district (Melbourne Airport, 2017c). Melbourne Airport is the State of Victoria's primary gateway for air travel, tourism, and freight (Melbourne Airport, 2017a). Melbourne Airport is Australia's second busiest airport. In July 1997, a long-term lease for the management and operation of Melbourne Airport was awarded to Australian Pacific Airports Corporation (Senguttuvan, 2007). At the time of the present study, Melbourne Airport was managed and operated by Australia Pacific Airports Corporation Limited (APAC) which is a privately held corporation that is owned by institutional investors, who are predominantly superannuation/pension funds (Australia Pacific Airports Corporation, 2019).

Melbourne Airport has four terminals, with Terminal 1 used for Qantas Airways domestic flights, Terminal 2 handles international flights, and Terminal 3 is used for Virgin Australia domestic services. Melbourne Airport officially opened its new Terminal 4 facility on 09 December 2015. The opening ceremony followed the gradual opening of the terminal to passengers in two stages. Tigerair Australia and Jetstar Airways commenced services from the terminal in the last few months of 2015 and Regional Express Airlines began services in early 2016. Melbourne Airport's Terminal 4 is located to the south of Terminal 3 and comprises 20,000 square metres of space over three levels. The facility has the capacity to accommodate up to 10 million passengers a year (Sadler, 2015).

The Melbourne Airport site is approximately 2,740 hectares in size. There is urban development to the east and south of the airport. This mainly consists of a mix of residential and industrial uses. Melbourne Airport has two runways. The longer Runway 16/34 measures 3.7 kilometres in length, while the shorter Runway 09/27 is 2.3 kilometres long (Australian Aviation, 2019b). Melbourne Airport has eighty aircraft stands that are used for the parking of aircraft (Australia Pacific Airports Corporation, 2019).

\subsubsection{Melbourne Airport Environmental Policy}

In 2018, Melbourne Airport defined and implemented a comprehensive environmental policy in which the airport committed to reducing its environmental impact. A key aspect of the policy is its desire to be an environmental leader for transport and logistics sites in the Asia Pacific region (Australia Pacific Airports Corporation, 2018).

In accordance with the environmental policy, Melbourne Airport is to be responsible for, and to protect the environment directly and indirectly by the airport's operations. The airport is also committed to the continuous 
improvement in its environmental performance using the certified Environmental Management System (EMS). The environmental policy also aims to make a material reduction in the energy consumption and the associated emissions by adopting measures to conserve natural resources and by adapting to climate change. Melbourne Airport's environmental policy also aims to minimize waste through the implementation of the waste management hierarchy and by adopting a life cycle approach to procurement. The airport also aims to reduce prevent, limit, and reduce pollution wherever possible. In accordance with its environmental policy, Melbourne Airport manages its land holdings to protect and enhance biodiversity and cultural heritage, whilst at the same time maintaining aircraft safety, which is a key priority. Melbourne Airport also ensures that it complies with all environmental and energy laws, policies, procedures, and other compliance obligations and, where appropriate, exceeds those requirements. A key aspect of the environmental policy is the airport's goal to make the best use of its facilities and design, and where needed, to construct and operate new facilities in support of the airport's environmental and sustainability goals (Australia Pacific Airports Corporation, 2018).

To achieve its environmental-related objectives, the airport authority works closely with its staff, tenants, business partners, regulatory agencies, and local and regional communities to develop new strategies to improve environmental performance whilst also protecting the environment (Australia Pacific Airports Corporation, 2018).

4.2.3 Melbourne Airport Environmental Management System (EMS)

In June 2004, Melbourne Airport became the first Australian airport to receive international certification of its Environmental Management System (EMS). At the time of the present study, Melbourne Airport's Environmental Management System (EMS) was being certified in accordance with the international standard ISO 14001:2015 (Melbourne Airport, 2017b).

4.2.4 Melbourne Airport Photovoltaic (PV) Solar Power System

During the period 2018 to 2021, Melbourne Airport installed three photovoltaic (PV) solar systems. The first system was a $12 \mathrm{MW}$ solar array that provides approximately $25 \%$ of the airport's energy needs (based on pre-COVID-19 levels), whilst the second system was comprised of a $1.8 \mathrm{MW}$ roof array on a warehouse located in the airport's Business Park. The final system was comprised of a $100 \mathrm{KW}$ array and $140 \mathrm{KW}$ battery solar array that is used to power an on-site water treatment plant (Melbourne Airport, 2017b).

The planning for these projects commenced in in 2018 (Thorn, 2020). Melbourne Airport's solar farm is one of Australia's largest behind the meter solar installations (Bates, 2020; International Airport Review, 2021; Matich 2020). The solar foam occupies an area of around 192,000m² (International Airport Review, 2021). The new solar farm at Melbourne Airport became operational in January 2021 and has the capability to produce enough renewable energy to power all four passenger terminals. The photovoltaic (PV) solar system can generate $17 \mathrm{GW}$ hours of electricity per annum. This is equal to around 15 per cent of the airport's total annual electricity consumption (Air Transport Action Group, 2020; Bates, 2020; Matich 2020).

The solar panels were installed at a site located off Sunbury Road. This site was selected as the location due to the available land, proximity to the airport and the maximum direct sunlight without obstructions (International Airport Review, 2021). The solar farm used Canadian-made solar mono-facial panels that were designed to avoid glare that could otherwise have caused problems around the airport's runways (Jamieson, 2020). To alleviate the possibility of dazzling pilots from the solar system, Melbourne Airport installed fixed ground racking systems (Youd, 2021).

Melbourne Airport has also installed a $2 \mathrm{MWdc}$ capacity array on the roof of the Agility Logistics' facility. This system is approximately $30,000 \mathrm{~m} 2$ in size and was the airport's first rooftop solar structure. The system will connect into the airport's embedded network (International Airport Review, 2021).

A key issue for Melbourne Airport was the surrounding wildlife and birds. To mitigate this problem, the shrubbery planted around the solar farm was kept simple, and does not produce any food for birds, such as seeds and berries (Youd, 2021).

\subsubsection{Melbourne Airport Trigeneration System}

In December 2016, Melbourne Airport completed the installation of its $8 \mathrm{MW}$ trigeneration plant (Australia Pacific Airports Corporation, 2017). The tri-generation power facility became operational in 2017. This system produces power, gas, and cooling. A key benefit of this system is that it turns excess heat into chilled and hot water (Melbourne Airport, 2017b). The airport's tri-generation facility has become a significant contributor to the airport's goal of reducing its carbon footprint (Australia Pacific Airports Corporation, 2017). 
The tri-generation plant provides power into the airport's high voltage network. Importantly, both the solar farm and the tri-generation plant can operate in unison. This because the airport's load is more than the sum of what the solar farm and tri-generation plant can produce (International Airport Review, 2021).

4.2.6. The Environmental Benefits of the Solar Power (PV) and Trigeneration Systems at Melbourne Airport

The use of the photovoltaic (PV) solar power and trigeneration systems are helping Melbourne Airport to reduces its energy consumption. The reduction in energy consumption allows the airport to reduce its operational greenhouse gas (GHG) emissions and will help the airport to move to towards carbon neutrality (Melbourne Airport, 2017b).

The trigeneration system is delivering significant environmental-related benefits for Melbourne Airport. The airport has estimated that the system will reduce the airport's carbon dioxide $\left(\mathrm{CO}_{2}\right)$ emissions by 920,000 tonnes over a 15 period (Melbourne Airport, 2017b).

In the long-term, Melbourne Airport plans to maintain its commitment and investment in renewable energy projects, thereby minimizing its carbon footprint and maximizing energy efficiency. The airport's solar farm is expected to provide a sustained amount of electricity, thus reducing the dependency for grid electricity. The solar farm will reduce peak electrical demand on the network with Melbourne Airport's peak electrical demand, typically experienced during sunshine hours (International Airport Review, 2021). Like the trigeneration system, the airport's solar systems will also reduce carbon dioxide $\left(\mathrm{CO}_{2}\right)$ emissions. This is because photovoltaic (PV) solar power systems do not produce air pollution or greenhouse gases (GHG) (United States Energy Information Agency, 2020).

\section{CONCLUSION}

Airports are extremely energy intensive and where energy is produced from fossil fuels then there are emissions, such as, carbon dioxide $\left(\mathrm{CO}_{2}\right)$, that are harmful to the environment. Considering the environmental impact of their operations, airports around the world are increasingly adopting the use of new "green" technologies to reduce their carbon footprint. This study has examined the approaches taken by Brisbane and Melbourne Airports in Australia to mitigate their carbon footprint using photovoltaic (PV) solar systems. Melbourne Airport is now operating a trigeneration system and this system is also underpinning the airport's goal to reduce to its carbon footprint.

The case study revealed that Brisbane Airport built a large scale $5 \mathrm{MWh}$ system on six sites that are located throughout the airport precinct. The system has incorporated both rooftop and ground-based solar panels. The photovoltaic (PV) solar system has delivered Brisbane Airport important environmental related benefits. The photovoltaic (PV) solar system provides around $18 \%$ of the airport's electricity and the system will meet approximately $6 \%$ of Brisbane Airport Corporation's overall load. In addition, the photovoltaic (PV) solar system has enabled the airport to reduce it carbon footprint, as the system has reduced the airport's carbon dioxide $\left(\mathrm{CO}_{2}\right)$ emissions by an estimated 8,000 tonnes per annum.

Like Brisbane Airport, Melbourne Airport has also taken steps to "green' its operations. The case study found that the airport has taken a multi-faceted approach to its energy policy. The trigeneration system works in parallel with the airport's new photovoltaic (PV) solar system, and this system is predicted to reduce the airport's carbon footprint by an estimated 920,000 tonnes over a 15 period. The first system photovoltaic (PV) solar system is a $12 \mathrm{MW}$ solar array that will provide approximately $25 \%$ of the airport's energy needs (based on pre-COVID-19 levels), whilst the second system is a $1.8 \mathrm{MW}$ roof array on a warehouse located in the airport's Business Park and the final system is a $100 \mathrm{KW}$ array and $140 \mathrm{KW}$ battery solar. the airport's solar systems will reduce the airport's annual carbon dioxide $\left(\mathrm{CO}_{2}\right)$ emissions. At the time of the present study, the annual carbon dioxide $\left(\mathrm{CO}_{2}\right)$ emissions data was not publicly available.

\section{REFERENCES}

[1] Ahmed, S.S.U., Salehin, S., Rahman, M.M., \& Sadral Islam, A.K.M. (2017). Harvesting solar energy: Fundamentals and applications. In P. Mondal \& A.K. Dalai (Eds.), Sustainable utilization of natural resources (pp. 381-416). Boca Raton, FL: CRC Press.

[2] Air Transport Action Group. (2020). Melbourne Airport's sustainable solar approach. Retrieved from https://aviationbenefits.org/newswire/2020/08/melbourneairport-s-sustainable-solar-approach.

[3] Akyüz, M.K., Altuntaş, O., \& Söğüt, M.Z. (2017). Economic and environmental optimization of an airport terminal building's wall and roof insulation. Sustainability, 9(10), 1849. https://doi.org/10.3390/su9101849

[4] Akyuz, M.K., Altuntas O., Sogut M.Z., \& Karakoc T.H. (2019). Energy management at the airports. In T. Karakoc, C. Colpan, O. Altuntas., \& Y. Sohret (Eds.), Sustainable aviation (pp. 9-36). Cham: Springer

[5] Andrew, D.P.S., Pedersen, P.M., \& McEvoy, C.D. (2011). Research methods and design in sport management. Champaign, IL: Human Kinetics. 
[6] Anurag, A., Zhang, J., Gwamuri, J., \& Pearce, J.M. (2017). General design procedures for airport-based solar photovoltaic systems. Energies, 10(8), 1194. https://doi.org/10.3390/en10081194

[7] Arman, H., \& Yuksel, I. (2013). Preface. In H. Arman \& I Yuksel (Eds.), New developments in renewable energy (pp. xi-xii). Rijeka: InTech.

[8] Aswathanarayana, U. (2010). Introduction. In U. Aswathanarayana., T. Harikrishan., \& K.M Thayyib Sahini. (Eds.), Green energy technology, economics, and policy (pp. 1-4). Boca Raton, FL: CRC Press.

[9] Australia Pacific Airports Corporation. (2017). APAC Annual Report 2016/17. Retrieved from http://www.melbourneairport.com.au/getattachment/Corpora te/About-us/Corporate-Information/Annual-reports/2017Annual-report-(1).pdf.

[10] Australia Pacific Airports Corporation. (2018). Environmental policy. Retrieved from https://www.melbourneairport.com.au/getattachment/Corpor ate/About-us/Environment/Environment-at-MelbourneAirport/Melbourne-Airport-Environment-Policy_August2018.pdf.

[11] Australia Pacific Airports Corporation. (2019). APAC Annual Report 2018/19. Retrieved fromhttp://www.melbourneairport.com.au/getattachment/Co rporate/About-us/Corporate-Information/Annualreports/AP003ia-4-APAC-AR19?_AW.pdf.

[12] Australian Aviation. (2017). Brisbane Airport unveils solar project. Retrieved from https://australianaviation.com.au/2017/09/brisbane-airportunveils-solar-project/.

[13] Australian Aviation. (2019a). Brisbane Airport solar panels project reaches practical completion. Retrieved from https://australianaviation.com.au/2019/05/brisbane-airportsolar-panels-project-reaches-practical-completion/.

[14] Australian Aviation. (2019b). Melbourne Airport proposes north-south orientation for third runway. Retrieved from https://australianaviation.com.au/2019/11/melbourneairport-proposes-north-south-orientation-for-third-runway.

[15] Baek, S., Kim, H., \& Joon Chang, H. (2016). Optimal hybrid renewable airport power system: Empirical study on Incheon International Airport, South Korea. Sustainability, 8(6), 562. https://doi.org/10.3390/su8060562

[16] Balfour, J.R., Shaw, M., \& Nash, N. (2013). Introduction to photovoltaic system design. Burlington, MA: Jones \& Bartlett Learning,

[17] Barrett, S., Devita, P., Ho. C., \& Miller, B. (2014). Energy technologies' compatibility with airports and airspace: Guidance for aviation and energy planners. Journal of Airport Management, 8(4), 318-326.

[18] Bates, J. 2020. New solar power plant being built at Melbourne Airport. Retrieved from https://airportworld.com/new-solar-power-plant-being-built-atmelbournes-tullamarine-airport/.

[19] Baxter, G. (2021). Achieving carbon neutral airport operations by 2025: The case of Sydney Airport, Australia. Transport and Telecommunication, 22(1), 1-14. https://doi.org/10.2478/ttj-2021-0001
[20] Baxter, G., Srisaeng, P., \& Wild, G. (2018a). Sustainable airport waste management: The case of Kansai International $\begin{array}{llll}\text { Airport. } & \text { Recycling, }\end{array}$ https://doi.org/10.3390/recycling3010006

[21] Baxter, G., Srisaeng, P., \& Wild, G. (2018b). An assessment of airport sustainability, Part 2-Energy management at Copenhagen Airport. Resources, 7(2), 32. https://doi.org/10.3390/resources7020032

[22] Baxter, G., Srisaeng, P., Wild, G. (2019). Environmentally sustainable airport energy management using solar power technology: The case of Adelaide Airport, Australia. International Journal for Traffic and Transport Engineering, 9(1), $81-100$.

[23] Bhattacharyya, S. 2015. Introduction. In P. Mohanty, T. Muneer, \& M. Kolhe (Eds.), Solar photovoltaic system applications: A guide for off-grid electrification (pp. 1-6). Cham, Switzerland: Springer Nature Switzerland.

[24] Bhowmik, C., Bhowmik, S.,Ray, A., \& Murari Pandey, K. (2017). Optimal green energy planning for sustainable development: A review. Renewable and Sustainable Energy Reviews, 71, 796-813. https://doi.org/10.1016/j.rser.2016.12.105

[25] Brisbane Airport. (2018). Brisbane Airport solar upgrade. Retrieved from https://www.bne.com.au/sites/default/files/docs/BAC3687Solar-Fact-Sheet-v4.pdf.

[26] Brisbane Airport. (2020). Brisbane Airport 2020 master plan. Retrieved from https://www.bne.com.au/sites/default/files/docs/BrisbaneAirport-2020-Master-Plan_0.pdf.

[27] Brisbane Airport. (2021). Guide to Brisbane International Airport. Retrieved from https://www.brisbane-airport.com/.

[28] Brisbane Development. (2017). New solar system set to slash BNE's energy needs. Retrieved fromhttps://brisbanedevelopment.com/new-solar-system-setto-slash-bnes-energy-needs/.

[29] Budd T. (2017). Environmental impacts and mitigation. In L. Budd \& S. Ison (Eds.), Air transport management: An international perspective (pp. 283-306). Abingdon, UK: Routledge.

[30] Clean Energy Regulator. (2021a). Large-scale generation certificates. Retrieved from http://cleanenergyregulator.gov.au/RET/Schemeparticipants-and-industry/Power-stations/Large-scalegeneration-certificates.

[31] Clean Energy Regulator. (2021b). What is a renewable energy certificate (REC)? Retrieved from https://recregistry.gov.au/rec-registry/app/public/what-is-a-rec.

[32] Comendador, V.F.G., Valdés, R.M.A., \& Lisker, B. (2019). A holistic approach to the environmental certification of green airports. Sustainability,11(5), 4043. https://doi.org/10.3390/su11154043

[33] Curran, S. (2016). Economic viability of using gridconnected photovoltaic energy in an airport in Jamaica. The Journal of the Association of Professional Engineers of Trinidad and Tobago, 44(1), 16-21.

[34] Daley, B. (2016). Air transport and the environment. Abingdon, UK: Routledge. 
[35] Dentch, M.P. (2016). The ISO 14001:2015 handbook: Using the process approach to building an environmental management system. Milwaukee, WI: Quality Press

[36] González-Ruiz,.D., Duque, E., Restrepo, J. 2017a. Green airport infrastructure in Colombia: Opportunities for publicprivate partnerships schemes. Pertanika Journal of Science \& Technology, 25, 37-46.

[37] Graham, A. (2018). Managing airports: An international perspective (5th ed.). Abingdon, UK: Routledge.

[38] Grandy, G. (2010). Instrumental case study. In A.J. Mills., G. Durepos., \& E. Wiebe (Eds.), Encyclopedia of case study research, Volume 1 (pp. 473-475). Thousand Oaks, CA: SAGE Publications.

[39] Grover, R.C., \& Grover, S. (2017). Winning the environmental challenge with ISO 14001: 2015: Implementation of an Environmental Management System. Chennai, India: Notion Press.

[40] Halcol Energy. (2019). Brisbane Airport gets solar upgrade. Retrieved from https://halcolenergy.com.au/solarnews/brisbane-airport-gets-solar-upgrade/.

[41] Heras-Saizarbitoria, I., Landín, G.A., \& Molina-Azorín, J.F. (2011). Do drivers matter for the benefits of ISO 14001? International Journal of Operations and Production Management, $\quad 31(2), \quad$ 192-216. https://doi.org/10.1108/01443571111104764

[42] International Airport Review. (2021). The sun shines on Melbourne Airport's new solar farm. Retrieved from https://www.internationalairportreview.com/article/146676/ melbourne-airport-solar-farm/.

[43] International Renewable Energy Agency. (2021). Benefits. Retrieved from https://www.irena.org/benefits.

[44] Jamieson, E. (2020). Melbourne Airport using down time to open solar farm in 2021. Retrieved from https://globetrender.com/2020/10/13/melbourne-airportsolar-farm/.

[45] Janić, M. (2011). Greening airports: Advanced technology and operations. London, UK: Springer-Verlag.

[46] Janić. M. (2017). The sustainability of air transportation: A quantitative analysis and assessment. Aldershot, UK: Ashgate Publishing.

[47] Jarach, D. 2017. Airport marketing: Strategies to cope with the new millenium. Abingdon, UK: Routledge.

[48] Kandt, A., \& Romero, R. (2014). Siting solar photovoltaics at airports. Retrieved from https://www.nrel.gov/docs/fy14osti/62304.pdf.

[49] Kalyani, V.L., Dudy, M.K., Pareek, S. (2015). Green energy: The need of the world. Journal of Management Engineering and Information Technology, 2(5), 18-26.

[50] Kramer, L.S. (2010). Airport revenue diversification: A synthesis of practice. Airport Cooperative Research Program Synthesis 19. Washington, DC: Transportation Research Board.

[51] Lenaghan, N. (2017). Brisbane Airport to save \$1m a year from massive solar array. Retrieved from https://www.afr.com/property/brisbane-airport-to-save-1ma-year-from-massive-solar-array-20170915-gyikfc.

[52] Maisch, M. (2019). Brisbane welcomes Australia's largest airport PV installation. Retrieved from https://www.pv- magazine-australia.com/2019/05/10/brisbane-welcomesaustralias-largest-airport-pv-installation/.

[53] Matich, B. (2020). Fly me to the sun, Melbourne Airport's record solar farm. Retrieved from https://www.pvmagazine-australia.com/2020/08/07/fly-me-to-the-sunmelbourne-airports-record-solar-farm/.

[54] Melbourne Airport. (2017a). Connecting Victoria to the world since 1 July 1970 . Retrieved from https://www.melbourneairport.com.au/Corporate/Aboutus/50th-anniversary\#.

[55] Melbourne Airport. (2017b). Environment at Melbourne Airport. Retrieved from https://www.melbourneairport.com.au/Corporate/Aboutus/Environment/Environment-at-Melbourne-Airport.

[56] Melbourne Airport. (2017c). Passenger information: Maps. Retrieved from https://www.melbourneairport.com.au/Passengers/Passenger -information/Maps.

[57] Mostafa, M.F.A., Abdel Aleem, S.H.E., \& Ibrahim, A.M. (2016). Using solar photovoltaic at Egyptian airports: Opportunities and challenges. In Proceedings of the Power Systems Conference (MEPCON), 2016 Eighteenth International Middle East, Cairo, Egypt, 27-29 December, 73-80.

[58] Mostafa, M.F.A., Abdel Aleem, S.H.E., \& Zobaa, A.F. (2016). Risk assessment and possible mitigation solutions for using solar photovoltaic at airports. In Proceedings of the Power Systems Conference (MEPCON), 2016 Eighteenth International Middle East, Cairo, Egypt, 27-29 December, 81-88.

[59] Oates, B.J. (2006). Researching information systems and computing. London, UK: SAGE Publications.

[60] O'Leary, Z. (2004). The essential guide to doing research. London, UK: SAGE Publications.

[61] Oliveira, J.A., Oliveira, O.J., Ometto, A.R., Ferraudo, A.S., \& Salgado, M.H. (2011). Environmental management system ISO 14001 factors for promoting the adoption of cleaner production practices. Journal of Cleaner Production, 133 ,

1384-1394. https://doi.org/10.1016/j.jclepro.2016.06.013

[62] Ortega Alba, S., \& Manana, M. (2016). Energy research in airports: A review. Energies, 9(5), 349. https://doi.org/10.3390/en9050349

[63] Ortego Alba, S.O., \& Manana, M. (2017). Characterization and analysis of energy demand patterns in airports. Energies, 10(1), 119. https://doi.org/10.3390/en10010119

[64] Owens, D.C., Sadler, T.D., \& Friedrichsen, P. (2021). Teaching practices for enactment of socio-scientific issues instruction: An instrumental case study of an experienced biology teacher. Research in Science Education, 51, 375398. https://doi.org/10.1007/s11165-018-9799-3

[65] Paul, J., \& De Groot, E. (2010). Strategic planning: Study of Brisbane Airport. Asian Case Research Journal, 14(2), 129. https://doi.org/10.1142/S0218927510001416

[66] Radomska, M., Chernyak, L., \& Samsoniuk, O. (2018). The improvement of energy-saving performance at Ukrainian airports. In T.H. Karakoç, C. Ozgur Colpan,, \& Y. Şöhret 
(Eds.), Advances in sustainable aviation (pp.189-203). Cham, Switzerland: Springer International Publishing.

[67] Rossi Dal Pozzo, F. (2015). EU legal framework for safeguarding air passenger rights. Cham, Switzerland: Springer International Publishing.

[68] Sadler, K. (2015). Melbourne Airport Terminal 4 officially opens. Retrieved from https://www.internationalairportreview.com/news/21446/me lbourne-airport-terminal-4-officially-opens.

[69] Scott, J. (2014). A dictionary of sociology (4th ed.). Oxford, UK: Oxford University Press.

[70] Scott, J., \& Marshall, G. (2009). A dictionary of sociology (3rd ed.). Oxford, UK: Oxford University Press.

[71] Senguttuvan, P.S. (2007). Principles of airport economics. New Delhi, India: Excel Books.

[72] Shakra Energy. (2019). Construction underway of massive solar installation at Brisbane Airport. Retrieved from https://shakraenergy.com/brisbane-airport-corporation/.

[73] Solanki, C.S., \& Singh, H.K. (2017). Anti-reflection and light trapping in c-Si solar cells. Singapore: Springer Nature Singapore.

[74] Solomon, L.D. (2009). The promises and perils of infrastructure privatization: The Macquarie Model. New York, NY: Palgrave Macmillian.

[75] Sorenson, R. (2021). "How can I get better?": An instrumental case study of three experienced music teachers and their journey to expertise. Contributions to Music Education, 46, 225-244.

[76] Sreenath, S., Sudhakar, K., \& Yusop, A.F. (2020). Technical assessment of captive solar power plant: A case study of Senai Airport, Malaysia. Renewable Energy, 152, 849-866. https://doi.org/10.1016/j.renene.2020.01.111

[77] Sreenath, S., Sudhakar, K., \& Yusop, A.F. (2021a). Effect of PV material, texturing, orientation and tracking on glare impact: A simulation study from an Indian Airport. Cleaner Engineering and Technology, 4, 100236. https://doi.org/10.1016/j.clet.2021.100236

[78] Sreenath, S., Sudhakar, K., \& Yusop, A.F. (2021b). Energyexergy-economic-environmental-energo-exergo-

enviroecono (7E) analysis of solar photovoltaic power plant: A case study of 7 airport sites in India. Sustainable Energy Technologies and Assessments, 47, 101352. https://doi.org/10.1016/j.seta.2021.101352

[79] Stake, R.E. (1995). The art of case study research. Thousand Oaks, CA: SAGE Publications.

[80] Stake, R.E. (2005). Qualitative case studies. In N.K. Denzin \& Y.S. Lincoln (Eds.), The SAGE handbook of qualitative research (pp. 443-466). Thousand Oaks, CA: SAGE Publications.

[81] Sukumaran, S., \& Sudhakar, K. (2017). Fully solar powered Raja Bhoj International Airport: A feasibility study. Resource Efficient Technologies, 3(3), 309-316. https://doi.org/10.1016/j.reffit.2017.02.001

[82] Thorn, A. (2020). Melbourne's gigantic solar farm to power on in January. Retrieved from https://australianaviation.com.au/2020/08/melbournesgigantic-solar-farm-to-power-on-in-january.
[83] Tretheway, M., \& Markhvida, K. (2013). Airports in the aviation value chain: Financing, returns, risk and investment. Retrieved from https://www.itfoecd.org/sites/default/files/docs/dp201315.pdf.

[84] Trina Solar. (2019). Australia's largest airport solar installation achieves practical completion. Retrieved from https://www.trinasolar.com/au/resources/newsroom/auaustra lia\%E2\%80\%99s-largest-airport-solar-installation-achievespractical-completion.

[85] United States Energy Information Agency. (2020). Solar explained: Solar energy and the environment. Retrieved from https://www.eia.gov/energyexplained/solar/solarenergy-and-the-environment.php.

[86] United States Environmental Protection Agency. (2021). Local renewable energy benefits and resources. Retrieved from https://www.epa.gov/statelocalenergy/local-renewableenergy-benefits-and-resources.

[87] West, J.J., Stanley, A.M., Bowers, J.P., \& Isbell, D.S. (2021). Attrition, (de)motivation, and "effective" music teacher professional development: An instrumental case study. Bulletin of the Council for Research in Music Education, 229, 7-28.

[88] Wybo, J.L. (2013). Large-scale photovoltaic systems in airport areas: Safety concerns. Renewable and Sustainable Energy Reviews, 21, 402-410. https://doi.org/10.1016/j.rser.2013.01.009

[89] Yerel Kandemir S., \& Yayli, M. Ö. (2016). Investigation of renewable energy sources for airports. In T. Hikmet, M. Baris Ozerdem, C.O. Colpan, O. Altuntas, E. Acikkalp (Eds.), Sustainable aviation: Energy and environmental issues (pp. 11-16). Cham, Switzerland: Springer International Publishing.

[90] Yin, R.K. (2018). Case study research and applications 6th ed.). Thousand Oaks: SAGE Publications.

[91] Youd, F. (2021). Sustainable energy: The airports harnessing green energy. Retrieved from https://www.airport-technology.com/features/sustainableenergy-the-airports-harnessing-green-energy/. 